
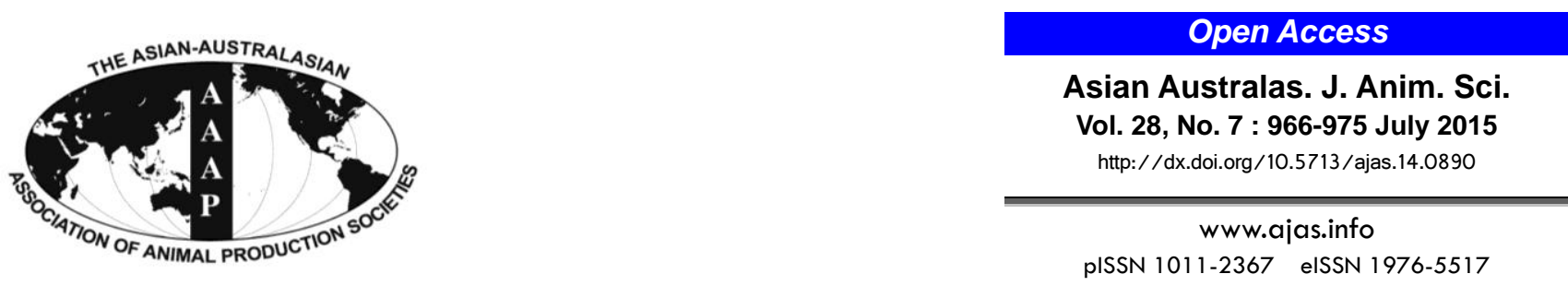

\title{
Nighttime Cooling Is an Effective Method for Improving Milk Production in Lactating Goats Exposed to Hot and Humid Environment
}

\author{
Katsunori Sunagawa*, Itsuki Nagamine, Yasuhiro Kamata, Noriko Niino, Yoshihiko Taniyama, \\ Kazuhide Kinjo, and Ayano Matayoshi \\ Faculty of Agriculture, University of the Ryukyus, Nishihara, Okinawa 903-0213, Japan
}

\begin{abstract}
Heat production in ruminants follows a diurnal pattern over the course of a day peaking 3 hours following afternoon feeding and then gradually declining to its lowest point prior to morning feeding. In order to clarify the cooling period most effective in reducing decreases in feed intake and milk production, experiments were carried out based on the diurnal rhythm of heat production and heat dissipation. In experiment 1 , the effects of hot environment on milk production were investigated. The animals were kept first in a thermoneutral environment $\left(20.0^{\circ} \mathrm{C}, 80.0 \%\right)$ for 12 days, they were then transitioned to a hot environment $\left(32^{\circ} \mathrm{C}, 80.0 \%\right)$ for 13 days before being returned to second thermoneutral environment for a further 12 days. In experiment 2, the effectiveness of daytime cooling or nighttime cooling for improving milk production in hot environment was compared. While ten lactating Japanese Saanen goats (aged 2 years, weighing $41.0 \mathrm{~kg}$ ) during early lactation were used in experiment 1, ten lactating goats (aged 2 years, weighing $47.5 \mathrm{~kg}$ ) during mid-lactation were used in experiment 2 . The animals were fed $300 \mathrm{~g}$ of concentrated feed and excessive amounts of crushed alfalfa hay cubes twice daily. Water was given ad libitum. The animals were milked twice daily. When exposed to a hot environment, milk yield and composition decreased significantly $(\mathrm{p}<0.05)$. Milk yield in the hot environment did not change with daytime cooling, but tended to increase with nighttime cooling. Compared to the daytime cooling, milk components percentages in the nighttime cooling were not significantly different but the milk components yields in the nighttime cooling were significantly higher $(\mathrm{p}<0.05)$. The results indicate that nighttime cooling is more effective than daytime cooling in the reduction of milk production declines in lactating goats exposed to a hot environment. (Key Words: Effective Cooling Periods, Heat Stress, Milk Production, Lactating Goats, Circadian Rhythm, Nighttime Cooling)
\end{abstract}

\section{INTRODUCTION}

Ruminants are diurnally active. During the day, the animals spend more time feeding and standing than is normally observed while they are at rest during the night (Yamamoto et al., 1979). More body heat is produced during feeding and standing than resting or lying down. Because ruminal fermentation and nutrient absorption in the lower digestive tract take place following feeding, a great deal of body heat is produced during the day. Therefore, the metabolic rate of diurnal animals is higher during the day

* Corresponding Author: Katsunori Sunagawa. Tel: +81-98-8958798, Fax: +81-98-895-8734, E-mail: b986094@agr.u-ryukyu.ac.jp Submitted Nov. 21, 2014; Revised Feb. 3, 2015; Accepted Feb. 13, 2015 than at night, and consequently the amount of body heat produced during the day is also higher than at night (Ando et al., 1997). Because of this, the body temperature of ruminants is higher during the day than at night.

There is very little research on heat loss in ruminants. Body heat from heat producing organs is transferred throughout the whole body and to the skin surface via blood circulation. It has been reported that in a thermoneutral environment, cardiac output of sheep during feeding is transferred more so to the abdominal and digestive organs than to the surface of the body (Hales, 1974). However, in a hot environment, in order to dissipate heat through evaporative heat loss, a greater amount of cardiac output is transferred to the body surface and respiratory tract (Hales, 1974). The efficiency of body heat dissipation is dependent 
upon the difference in the temperature of the surface of the body and the ambient temperature.

Fans, sprinklers and fans, and a combination of misters and fans, and nutritional modification have all been the focus of research on reducing heat stress and subsequent reductions in feed intake and milk production in lactating cows in a hot environment (West, 1999; 2003). However, there is no research of cooling methods based on the circadian rhythm of heat production and heat dissipation in animals. From the above reports, it is thought that decreases in milk production of lactating goats in hot environment may be reduced effectively by nighttime cooling (NC) when heat producing activity of the day is reduced and body heat is more readily transferred to the surface of the body for dissipation.

In order to prove this hypothesis, this research compared the effects of both day and night $12 \mathrm{~h}$ cooling periods on the reduction of milk production decreases in lactating goats exposed to hot environment.

\section{MATERIALS AND METHODS}

Experiment 1: The effect of hot environment on total digestible nutrients and digestible crude protein intakes, and milk production

Animals: Ten lactating goats (Japanese Saanen, aged 2 years, two parities, 32 to 43 days after parturition, weighing $41.0 \pm 4.1 \mathrm{~kg}$ ) were used in the experiment. The goats were maintained in individual metabolic cages (length $2 \mathrm{mx}$ width $1 \mathrm{~m} \times$ height $2 \mathrm{~m}$ ) that allowed for the separate collection of urine and feces. The climatic room was maintained under thermoneutral conditions (room temperature $20.0 \pm 0.55^{\circ} \mathrm{C}$, relative humidity $80.0 \pm 1.80 \%$ ). The animals were given excessive amounts of roughly crushed alfalfa hay cubes (more than could be consumed) and $300 \mathrm{~g}$ of concentrated feed twice a day.

Experimental design: All the animals were kept in a thermoneutral environment (first thermoneutral environment, room temperature $20.0 \pm 0.55^{\circ} \mathrm{C}$, relative humidity $80.0 \pm 1.80 \%$ ) for 12 days, they were then transitioned to a hot environment $\left(32^{\circ} \mathrm{C}, 80.0 \pm 1.80 \%\right)$ for 13 days before being returned to a thermoneutral environment (second thermoneutral environment, room temperature $20.0 \pm 0.55^{\circ} \mathrm{C}$, relative humidity $80.0 \pm 1.80 \%$ ) for a further 12 days. The thermoneutral environment has been understood as the zone of minimal heat production at normal rectal temperature (Kadzere et al., 2002). Within the thermoneutral environment, minimal physiological costs and maximum productivity are normally achieved (Johnson, 1987). It was reported that upper critical temperature for goats in maintenance is $25^{\circ} \mathrm{C}$ to $30^{\circ} \mathrm{C}$, but this has not been fully established for growing and lactating goats ( $\mathrm{Lu}, 1989)$. Based on these reports, thermoneutral conditions used for the cooling treatment in this experiment were set at $20^{\circ} \mathrm{C}$, relative humidity $80 \%$. In order to produce heat stress, the hot environment was set to $32^{\circ} \mathrm{C}$, relative humidity $80 \%$. These temperature and humidity conditions are typical of summers in Okinawa.

In each environment, the animals' heart rate, respiration rate, and rectal temperature were measured twice daily $(8: 30,16: 00)$. Feed intake and water intake were also measured. The animals were milked twice a day at 9:00 and again at 17:00. Each of the animals in all groups was given excessive amounts of roughly crushed alfalfa hay cubes (more than could be consumed) and $300 \mathrm{~g}$ of concentrated dairy cow feed twice a day $(9: 30,17: 30)$. The animals were allowed to eat freely. In order to measure the amount of feed and water intake, the remaining feed and water was collected $1 \mathrm{~h}$ prior to new feed being given. The weight of the remaining feed and water was then subtracted from the original amount to give total feed and water intake for the feeding period. The measurements from both the feeding periods (morning and afternoon) were then combined to give a total daily feed and water intake.

Respiration rate was measured by counting with a stethoscope, and observing and counting thoracic movement that occurs in conjunction with respiration (Thang et al., 2011). Heart rate was measured by counting heart sounds with a stethoscope placed $5 \mathrm{~cm}$ behind the left olecranon. Rectal temperature was measured by inserting a veterinary thermometer approximately $10 \mathrm{~cm}$ into the rectum for about $10 \mathrm{~min}$. Feed intake and water intake were measured by calculating the difference between the amount of feed and water given to the animals and the amount left over after feeding. A $6 \mathrm{~kg}$ measuring scale was used to weigh the feed and water.

Milk yield was measured using a $500 \mathrm{~mL}$ measuring cylinder. In order to measure milk composition (fat, protein, lactose, solids-non-fat, total solids), an $80 \mathrm{~mL}$ sample of milk was taken during both the morning and afternoon milking. The samples were stored in a refrigerator at $4^{\circ} \mathrm{C}$ until they were analyzed the next day.

All experimental procedures were in compliance with the Japanese code of practice for the care and use of animals for scientific purposes.

Chemical analysis of feeds and milk composition: The chemical composition of alfalfa hay cubes and concentrated feed are shown in Table 1. Alfalfa hay cubes and concentrated feed were subjected to draught drying $\left(70^{\circ} \mathrm{C}\right.$, $24 \mathrm{~h}$ ) and then were ground with a Wiley mill (type 40-525P, Ikemoto, Rika Kougyou, Tokyo, Japan). The chemical components of the feed were quantified using the procedures described by the AOAC (1990). The chemical component analysis was conducted in triplicate for each type of feed. The dry matter (DM) content was quantified by oven drying at $135 \pm 2^{\circ} \mathrm{C}$ for $2 \mathrm{~h}$. The crude protein 
Table 1. Chemical composition of alfalfa hay cubes and concentrated feed

\begin{tabular}{|c|c|c|}
\hline Item & $\begin{array}{c}\text { Alfalfa } \\
\text { hay cubes }\end{array}$ & $\begin{array}{c}\text { Concentrated } \\
\text { feed }\end{array}$ \\
\hline Dry matter $(\%)$ & 86.3 & 87.2 \\
\hline \multicolumn{3}{|l|}{ Chemical composition (\%DM) } \\
\hline $\mathrm{OM}$ & 8.4 & 93.2 \\
\hline $\mathrm{CP}$ & 15.4 & 16.6 \\
\hline $\mathrm{EE}$ & 2.4 & 2.6 \\
\hline $\mathrm{CF}$ & 26.5 & 3.1 \\
\hline $\mathrm{NDF}$ & 38.9 & 14.6 \\
\hline $\mathrm{ADF}$ & 30.4 & 5.4 \\
\hline NFE & 42.1 & 71.0 \\
\hline TDN & 50.7 & 70.0 \\
\hline DCP & 10.9 & 14.0 \\
\hline \multicolumn{3}{|l|}{ Ingredients (\%) } \\
\hline Maize & & 48.0 \\
\hline Sorghum & & 24.0 \\
\hline Barley & & 1.0 \\
\hline Soybean meal & & 3.5 \\
\hline Rapeseed meal & & 9.5 \\
\hline Wheat bran & & 6.0 \\
\hline Rice bran & & 5.0 \\
\hline Molasses & & 0.5 \\
\hline Calcium carbonate & & 1.4 \\
\hline Alfalfa meal & & 0.5 \\
\hline Sodium chloride & & 0.5 \\
\hline Dicalcium phosphate & & 0.05 \\
\hline Vitamin trace mineral premix & & 0.05 \\
\hline
\end{tabular}

DM, dry matter; OM, organic matter; CP, crude protein; EE, ether extract; $\mathrm{CF}$, crude fiber; NDF, neutral detergent fiber; $\mathrm{ADF}$, acid detergent fiber; NFE, nitrogen free extracts; TDN, total digestible nutrients; DCP, digestible crude protein.

content was calculated from the nitrogen content of the feed determined by Kjeldhal technique (AOAC, 1990). The ether extract content of feed was determined by continuous extraction with ethyl ether for $16 \mathrm{~h}$ using a Soxhlet extraction apparatus. Crude fiber was determined by subjecting the residue from ether extraction to successive treatments with boiling sulfuric acid $(1.25 \%)$ and sodium hydroxide $(1.25 \%)$. Nitrogen-free extract was calculated by subtraction of the sum of moisture, ash, crude protein, crude fat and crude fiber content from 100 . The acid-detergent fiber and neutral-detergent fiber were determined as described Van Soest et al. (1991).

The total digestible nutrients (TDN) and digestible crude protein (DCP) contents in feed were calculated using the digestibility of the ingredients that were measured in previous report (Table 1; Nagamine and Sunagawa, 2014). The TDN and DCP intakes were also calculated by feed intake, and the TDN and DCP contents in feeds.

Milk contents of fat, protein, lactose, solid-not-fat and total solid were analyzed by Milko Scan 104 infrared analyzer (A/SN, Foss Electric, Hillerod, Denmark).

Experiment 2: Effects of daytime cooling or nighttime cooling on reducing decreased milk production in lactating goats exposed to hot environment

Animals: Ten lactating goats (Japanese Saanen, two parities, 133 to 155 days after delivery, body weight $47.5 \pm 0.75 \mathrm{~kg}$ ) were used in the experiment. The animals used were the same as those used in Experiment 1. The goats were maintained in individual metabolic cages (length 2 mxwidth $1 \mathrm{~m} \times$ height $2 \mathrm{~m}$ ) that allowed for the separate collection of urine and feces. The animals were kept in a climatic room in preparation for the experiments. The climatic room was maintained under thermoneutral conditions (room temperature $20.0 \pm 0.55^{\circ} \mathrm{C}$, relative humidity $80.0 \pm 1.80 \%$ ). The animals were given excessive amounts of roughly crushed alfalfa hay cubes (more than could be consumed) and $300 \mathrm{~g}$ of concentrated feed twice a day $(9: 30,17: 30)$. The animals were given free access to drinking water.

Experimental design: Experiment 2 consisted of daytime cooling (DC) treatment, and NC treatment. The DC treatment ran for a total of 22 days. For the first 7 days, the animals were exposed to a hot environment (room temperature $32.0 \pm 0.55^{\circ} \mathrm{C}$, relative humidity $80.0 \pm 1.80 \%$ ). From day 8 through day 22, the climate in the room was adjusted to thermoneutral conditions (room temperature $20.0 \pm 0.55^{\circ} \mathrm{C}$, relative humidity $80.0 \pm 1.80 \%$ ) for 12 hours between the hours of 8 am to $8 \mathrm{pm}$. The room was returned to hot environment conditions during the nighttime. Following the conclusion of the DC treatment, the NC treatment ran for a total of 23 days. For the first 8 days, the animals were exposed to a hot environment (room temperature $32.0 \pm 0.55^{\circ} \mathrm{C}$, relative humidity $80.0 \pm 1.80 \%$ ). From day 9 through day 23 the climate in the room was adjusted to thermoneutral conditions (room temperature $20.0 \pm 0.55^{\circ} \mathrm{C}$, relative humidity $80.0 \pm 1.80 \%$ ) for 12 hours between the hours of $8 \mathrm{pm}$ to $8 \mathrm{am}$. The room was returned to hot environment conditions during the daytime.

Respiration rate, heart rate and rectal temperature for the animals in both groups were measured twice daily (8:30, 16:30). Following this, feed and water intake were also measured. The animals were milked twice daily (9:00, 17:00). The respiration rate, heart rate and rectal temperature of the animals were recorded every 30 to 60 minutes for a 24 hour period ( 7 am to 7 am the following day) for a total of 3 days for each treatment. The recordings in the DC treatment were made on day 7 (hot environment), day 16 and day 22 (under cooling conditions). The recordings in the NC treatment were made on day 8 (hot environment), day 17 and day 23 (under cooling conditions).

Rectal temperature was continuously recorded using a thermocouple (type T, copper-constantan, Ishikawa sangyou, 
Tokyo, Japan) connected to an LR8100 recorder (type 3710, Yokokawa denki, Tokyo, Japan). Feed intake, water intake, milk yield and milk compositions were measured as same as Experiment 1. The TDN and DCP intakes were also calculated as same as Experiment 1.

\section{Statistical analysis}

While feed intake, water intake, and milk yield were measured each day, in order to mitigate the carry over effects of the previous environment, only the values from the last 7 days of each of the environments were used in the statistical analysis.

The decrease in each measured parameter due to heat exposure was calculated using the following formula.

\section{HE percentage decrease $=(\mathrm{TE}-\mathrm{HE}) / \mathrm{TE} \times 100$}

Where $\mathrm{TE}=$ the thermoneutral environment; $\mathrm{HE}=$ the hot environment.

Reduction in decreased parameters by cooling in each measured parameter due to heat stress was calculated using the following formula.

Reduction in decreased parameters by cooling

$=(\mathrm{CT}-\mathrm{HE}) / \mathrm{HE} \times 100$

Where $\mathrm{CT}=$ daytime cooling or nighttime cooling treatment, $\mathrm{HE}=$ hot environment.

The data gathered from all ten goats used in the experiment were statistically analyzed as a repeated measurement. A two-way analysis (animal, environment) of variance was performed. After this, Duncan's Multiple Range Test was used to compare treatments. For statistical analysis, general linear model procedure of SAS (SAS Inst., Cary, NC, 1990) was adopted.

All data were analyzed using the following model:

$\mathrm{Y}_{\mathrm{ijk}}=\mu+\mathrm{A}_{\mathrm{i}}+\mathrm{E}_{\mathrm{j}}+(\mathrm{A} \times \mathrm{E})_{\mathrm{ij}}+\varepsilon_{\mathrm{ijk}}$

Where $\mathrm{Y}_{\mathrm{ijk}}=$ the measured variables; $\mu=$ the overall mean; $A_{i}=$ the effect of animal; $E_{j}=$ the effect of environment; $(\mathrm{A} \times \mathrm{E})_{\mathrm{ij}}=$ the interaction of animal and environment; $\varepsilon_{\mathrm{ijk}}=$ the random error effect.

\section{RESULTS}

Experiment 1: The effects of hot environment on physiological parameters, total digestible nutrients and digestible crude protein intakes, and milk production

Effects of hot environment on physiological parameters: The respiration rate, heart rate and rectal temperature of the animals in the first thermoneutral environment and the second the rmoneutral environment was $38 \pm 11.3,20 \pm 6.9$ breaths/min; $96 \pm 9.8,92 \pm 9.3$ beats $/ \mathrm{min}$; and $39.1 \pm 0.15$, $38.9 \pm 0.11^{\circ} \mathrm{C}$, respectively. Compared to the thermoneutral environment, the respiration rate $(146 \pm 15.3$ breaths $/ \mathrm{min})$ and rectal temperature $\left(40.2 \pm 0.17^{\circ} \mathrm{C}\right)$ in the hot environment both increased significantly $(\mathrm{p}<0.01)$, while heart rate $(70 \pm 8.9$ beats/min) decreased.

Effects of hot environment on TDN and DCP intakes: Table 2 shows TDN intake, DCP intake, water intake and body weight in thermoneutral and hot environments. The TDN and DCP intakes in the hot environment significantly decreased $(p<0.05)$ compared to intake in the first and second thermoneutral environment. The water intake significantly increased $(\mathrm{p}<0.05)$ in the hot environment compared to the first and second thermoneutral environments. The body weight in the hot environment significantly decreased $(\mathrm{p}<0.05)$ compared to the first and second thermoneutral environments.

Effects of hot environment on milk production: Table 3 and 4 show milk yield, milk composition and milk components yield in thermoneutral and hot environments. The milk yield in the hot environment significantly decreased $(p<0.05)$ compared to the first and second thermoneutral environments. The concentrations of milk fat, protein, lactose, solid-not-fat and total solid in the hot environment were significantly lower $(p<0.05)$ than in the first and second thermoneutral environments. The yields of milk fat, protein, lactose, solid-not-fat, and total solid in the

Table 2. Effects of hot environment on TDN and DCP intake during ad libitum feeding of dry forage

\begin{tabular}{lcccc}
\hline \multirow{2}{*}{ Item } & \multicolumn{3}{c}{ Environment } & SEM \\
\cline { 2 - 4 } & First thermoneutral $\left(20^{\circ} \mathrm{C}\right)$ & Hot $\left(32^{\circ} \mathrm{C}\right)$ & Second thermoneutral $\left(20^{\circ} \mathrm{C}\right)$ & 46.10 \\
Hay cubes intake $(\mathrm{g} \mathrm{DM} / \mathrm{d})$ & $1,690.8^{\mathrm{a}}$ & $784.3^{\mathrm{b}}$ & $1,800.1^{\mathrm{c}}$ & 0.00 \\
Formula feed intake $(\mathrm{g} \mathrm{DM} / \mathrm{d})$ & $518.0^{\mathrm{a}}$ & $518.0^{\mathrm{b}}$ & $518.0^{\mathrm{c}}$ & 23.15 \\
TDN intake $(\mathrm{g} / \mathrm{d})$ & $1,356.9^{\mathrm{a}}$ & $847.5^{\mathrm{b}}$ & $1,418.4^{\mathrm{c}}$ & 4.61 \\
DCP intake $(\mathrm{g} / \mathrm{d})$ & $247.9^{\mathrm{a}}$ & $146.4^{\mathrm{b}}$ & $260.2^{\mathrm{c}}$ & 0.61 \\
Water intake $(\mathrm{kg} / \mathrm{d})$ & $7.7^{\mathrm{a}}$ & $14.8^{\mathrm{b}}$ & $9.6^{\mathrm{c}}$ & 4.17 \\
Body weight $(\mathrm{kg})$ & $40.2^{\mathrm{a}}$ & $35.1^{\mathrm{b}}$ & $40.3^{\mathrm{a}}$ & \\
\hline
\end{tabular}

TDN, total digestible nutrients; DCP, digestible crude protein; SEM, standard error of the mean; DM, dry matter.

${ }^{\mathrm{a}, \mathrm{b}, \mathrm{c}}$ Comparison among first thermoneutral, hot and second thermoneutral environments.

${ }^{a, b, c}$ Means with different superscripts are significantly different $(\mathrm{p}<0.05)$.

Values are means of ten animals. 
Table 3. Effects of hot environment on milk yield and composition during ad libitum feeding of dry forage

\begin{tabular}{lcccc}
\hline \multirow{2}{*}{ Item } & \multicolumn{3}{c}{ Environment } & \multirow{2}{*}{ SEM } \\
\cline { 2 - 4 } & First thermoneutral $\left(20^{\circ} \mathrm{C}\right)$ & Hot $\left(32^{\circ} \mathrm{C}\right)$ & Second thermoneutral $\left(20^{\circ} \mathrm{C}\right)$ & 39.192 \\
Milk yield (g/day) & $1,880.0^{\mathrm{a}}$ & $1,611.7^{\mathrm{b}}$ & $1,932.6^{\mathrm{a}}$ & 0.091 \\
Milk composition (\%) & & & & $3.33^{\mathrm{b}}$ \\
$\quad$ Fat & $3.76^{\mathrm{a}}$ & $3.25^{\mathrm{b}}$ & $2.80^{\mathrm{a}}$ & 0.066 \\
Protein & $2.91^{\mathrm{a}}$ & $2.54^{\mathrm{b}}$ & $4.23^{\mathrm{b}}$ & 0.042 \\
Lactose & $4.50^{\mathrm{a}}$ & $4.14^{\mathrm{b}}$ & $8.09^{\mathrm{c}}$ & 0.102 \\
Solid-not-fat & $8.48^{\mathrm{a}}$ & $7.74^{\mathrm{b}}$ & $11.42^{\mathrm{b}}$ & 0.182 \\
Total solid & $12.24^{\mathrm{a}}$ & $10.99^{\mathrm{b}}$ & & \\
\hline
\end{tabular}

SEM, standard error of the mean.

a,b,c Comparison among first thermoneutral, hot and second thermoneutral environments.

a,b,c Means with different superscripts are significantly different $(\mathrm{p}<0.05)$.

Values are means of ten animals.

hot environment were significantly lower $(p<0.01)$ than in the first and second thermoneutral environments.

\section{Experiment 2: Daytime cooling or nighttime cooling for improving milk production in hot environment}

Reducing effects of cooling on physiological parameters in hot environment: Figure 1 shows the effects of daytime cooling on physiological parameters. While respiration rate in the hot environment was 110 to 115 breaths/min, it dropped significantly $(\mathrm{p}<0.01)$ to 30 to 40 breaths $/ \mathrm{min} 90$ min after cooling was commenced. This deceased respiration rate was maintained for $10.5 \mathrm{~h}$. Respiration rate returned to pre-cooling levels $120 \mathrm{~min}$ after the end of the cooling period. Heart rate increased significantly $(p<0.01)$ in the cooling period to 85 to 115 beats/min from 65 to 75 beats/min in the hot environment. Rectal temperature in the hot environment was $39.4^{\circ} \mathrm{C}$ to $40.3^{\circ} \mathrm{C}$. This decreased significantly ( $\mathrm{p}<0.01$ ) to $38.3^{\circ} \mathrm{C}$ to $38.6^{\circ} \mathrm{C}$ after $90 \mathrm{~min}$ of cooling and was maintained for $10.5 \mathrm{~h}$. Rectal temperature returned to pre-cooling levels $180 \mathrm{~min}$ after the end of the cooling period. Figure 2 show the effects of nighttime cooling on physiological parameters. Effects of nighttime

Table 4. Effects of hot environment on milk component yield during ad libitum feeding of dry forage

\begin{tabular}{lcccr}
\hline & \multicolumn{4}{c}{ Environment } \\
\cline { 2 - 4 } Item & $\begin{array}{c}\text { First } \\
\text { thermoneutral } \\
\left(20^{\circ} \mathrm{C}\right)\end{array}$ & $\begin{array}{c}\text { Hot } \\
\left(32^{\circ} \mathrm{C}\right)\end{array}$ & $\begin{array}{c}\text { Second } \\
\text { thermoneutral } \\
\left(20^{\circ} \mathrm{C}\right)\end{array}$ & SEM \\
\hline Component yield $(\mathrm{g} / \mathrm{d})$ & & & & \\
Fat & $71.3^{\mathrm{a}}$ & $52.6^{\mathrm{b}}$ & $64.8^{\mathrm{a}}$ & 2.696 \\
Protein & $55.1^{\mathrm{a}}$ & $41.1^{\mathrm{b}}$ & $54.5^{\mathrm{a}}$ & 2.053 \\
Lactose & $84.8^{\mathrm{a}}$ & $66.9^{\mathrm{b}}$ & $82.0^{\mathrm{a}}$ & 2.200 \\
Solid-not-fat & $159.9^{\mathrm{a}}$ & $125.1^{\mathrm{b}}$ & $157.0^{\mathrm{a}}$ & 4.571 \\
Total solid & $231.2^{\mathrm{a}}$ & $177.7^{\mathrm{b}}$ & $221.8^{\mathrm{a}}$ & 7.137 \\
\hline $\begin{array}{l}\text { SEM, standard error of the mean. } \\
\text { a,b,c } \text { Comparison among first thermoneutral, hot and second thermoneutral }\end{array}$ \\
$\begin{array}{l}\text { environments. } \\
\text { a,b,c Means with different superscripts are significantly different }(\mathrm{p}<0.05) .\end{array}$ \\
Values are means of ten animals.
\end{tabular}

cooling on respiration rate, heart rate, and rectal temperature in the hot environment were very similar to the effects recorded during daytime cooling.

Reducing effects of cooling on decreases in TDN and DCP intakes in hot environment: Table 5 shows effects of daytime or nighttime cooling on feed intake, water intake and body weight in goats exposed to hot environment. Hay cube intake, TDN intake, and DCP intake in the hot environment with daytime cooling all increased significantly $(53.2 \%, 39.2 \%, 40.1 \%)(\mathrm{p}<0.05)$. Water intake, however, decreased by $23.3 \%$. The body weight tended to increase by $6.1 \%$ in the hot environment.

By contrast, hay cube, TDN, and DCP intakes in the hot environment with nighttime cooling all increased significantly $(87.6 \%, 57.1 \%, 58.9 \%)(\mathrm{p}<0.05)$. Water intake, however, decreased by $29.0 \%$. The body weight tended to increase by $4.9 \%$ in the hot environment.

Compared to the daytime cooling period, the degree of hay cube, TDN, and DCP intakes were all significantly higher $(\mathrm{p}<0.05)$ in the nighttime cooling period.

Reducing effects of cooling on decreases in milk production in hot environment: Table 6 shows effects of daytime or nighttime cooling on milk yield, milk composition and components yield in goats exposed to hot environment. Milk yield in the hot environment did not change with daytime cooling. However, milk fat, protein, lactose, solid-not-fat and total solid percentages in the hot environment all significantly $(\mathrm{p}<0.05)$ increased $(13.5 \%$, $13.5 \%, 6.3 \%, 7.8 \%, 9.3 \%$ ) due to daytime cooling. Furthermore, milk fat, protein, lactose, solid-not-fat, and total solid yields in the hot environment all significantly $(p<0.05)$ increased $(10.1 \%, 10.0 \%, 3.1 \%, 4.6 \%, 6.1 \%)$ due to daytime cooling.

In the hot environment, there was a tendency for milk yield to increase when nighttime cooling was used. Milk protein, lactose, solid-not-fat and total solid percentages in the hot environment all significantly $(\mathrm{p}<0.05)$ increased $(10.2 \%, 6.2 \%, 6.7 \%, 6.8 \%)$ due to nighttime cooling. Furthermore, milk fat, protein, lactose, solid-not-fat and 
total solid yields in the hot environment all significantly $(p<0.05)$ increased $(9.8 \%, 11.9 \%, 9.0 \%, 9.1 \%, 9.3 \%)$ due to nighttime cooling.

Compared to the daytime cooling treatment, milk components percentages in the nighttime cooling treatment were not significantly different but overall, all the milk components yields in the nighttime cooling treatment were significantly higher $(\mathrm{p}<0.05)$.

\section{DISCUSSION}

Physiological parameters, total digestible nutrients, and digestible crude protein intakes, and milk production in hot environment

Sunagawa et al. (2002) reported that both rectal temperature and heart rate in goats exposed to a hot environment increased with feeding the same as in thermoneutral conditions. Compared to non-lactating animals, lactating animals consume large amounts of energy and produce large amounts of heat. Because the heat dissipation efficiency from the surface to the outside of the body is reduced in hot environment, lactating animals are exposed to an excessive heat load (West, 1997; Figures 1 and 2). In hot environment, respiration rate in ruminants markedly increases as body heat dissipation is carried out by vaporization heat via water vaporization in the respiratory tract.

In the hot environment of this experiment, respiration rate increased significantly $(\mathrm{p}<0.05)$ from 38 breaths $/ \mathrm{min}$ in the thermonuetral environment to 146 breaths/min in the
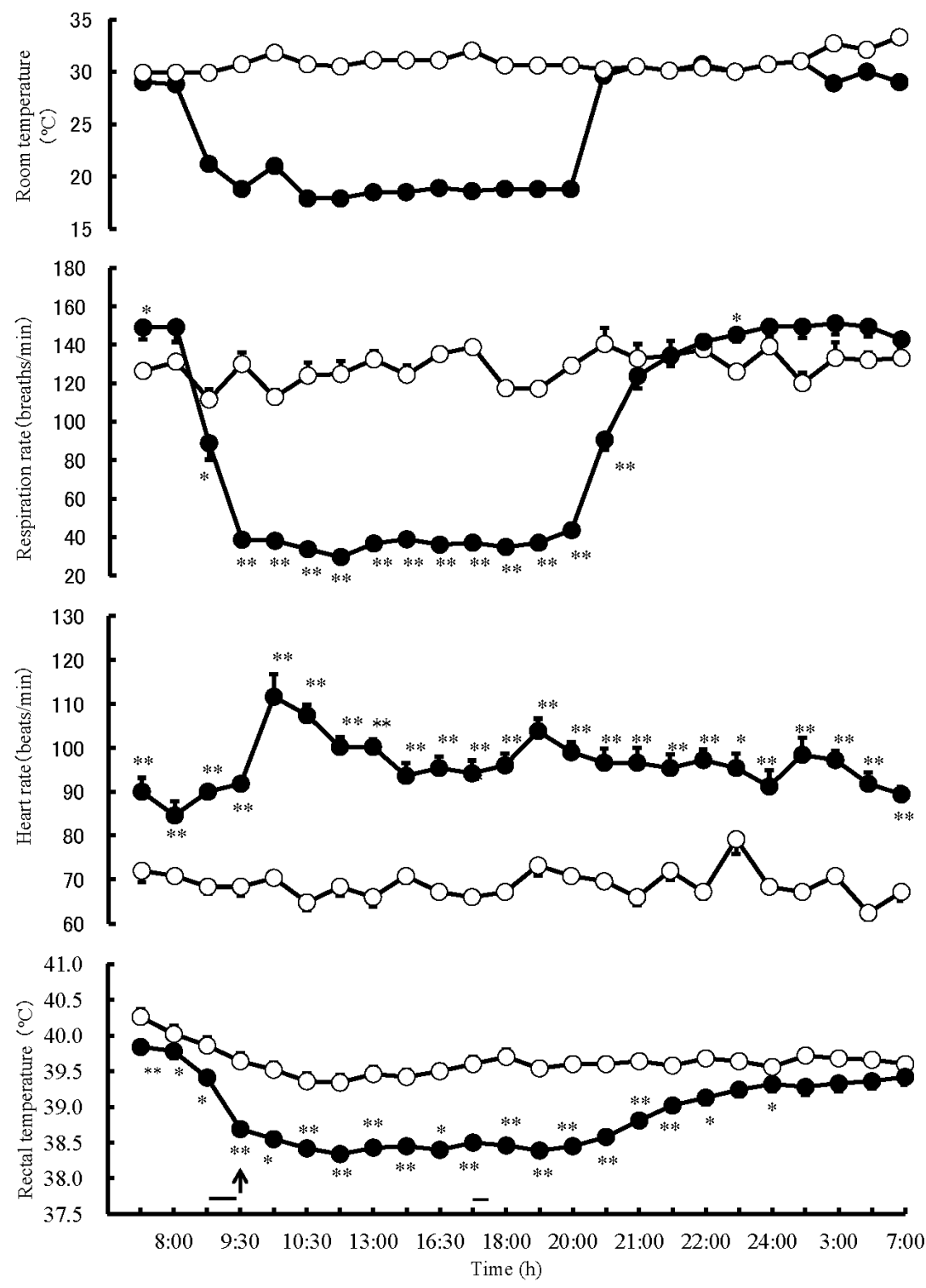

Figure 1. Effects of daytime cooling on respiration rate, heart rate and rectal temperature. Values are indicated by mean \pm standard error of ten animals in hot $(\circ)$ and daytime cooling $(\bullet)$ environments. Arrows $(\uparrow)$, bars $(-)$ indicate feeding and milking, respectively. Significance from hot environment $(* \mathrm{p}<0.05, * * \mathrm{p}<0.01)$. 

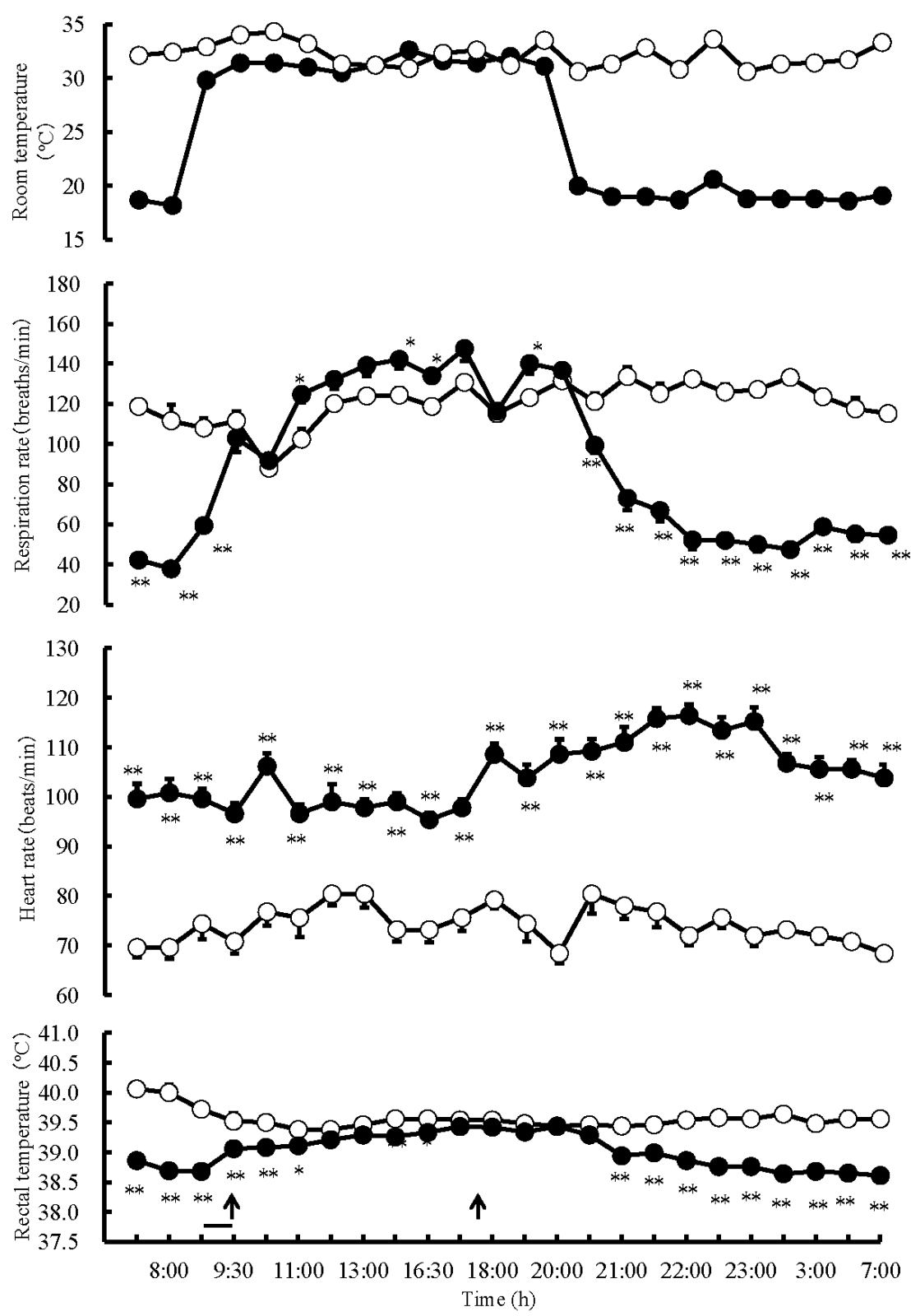

Figure 2. Effects of nighttime cooling on respiration rate, heart rate and rectal temperature. Values are indicated by mean \pm standard error of ten animals in hot $(\circ)$ and nighttime cooling $(\bullet)$ environments. Arrows $(\uparrow)$, bars $(-)$ indicate feeding and milking, respectively. Significance from hot environment $(* \mathrm{p}<0.05, * * \mathrm{p}<0.01)$.

Table 5. Effects of daytime or nighttime cooling on feed intake, water intake and body weight in goats exposed to a hot environment

\begin{tabular}{|c|c|c|c|c|c|}
\hline Item & $\begin{array}{c}\text { Hot } \\
\left(32^{\circ} \mathrm{C}\right)\end{array}$ & $\begin{array}{c}\text { Daytime } \\
12 \mathrm{~h} \text { cooling }\end{array}$ & $\begin{array}{c}\text { Hot } \\
\left(32^{\circ} \mathrm{C}\right)\end{array}$ & $\begin{array}{l}\text { Nighttime } \\
12 \text { h cooling }\end{array}$ & SEM \\
\hline Hay cube intake $(\mathrm{g} \mathrm{DM} / \mathrm{d})^{1}$ & $1,213.4^{\mathrm{b}}$ & $1,859.1^{\mathrm{a}}$ & $1,048.6^{\mathrm{b}}$ & $1,966.9^{\mathrm{c}}$ & 19.78 \\
\hline Concentrate intake (g DM/d) & 448.6 & 505.1 & 494.0 & 551.3 & 6.58 \\
\hline TDN intake $(\mathrm{g} / \mathrm{d})$ & $809.3^{\mathrm{b}}$ & $1,127.0^{\mathrm{a}}$ & $765.4^{\mathrm{b}}$ & $1,202.7^{\mathrm{c}}$ & 9.56 \\
\hline DCP intake $(\mathrm{g} / \mathrm{d})$ & $168.3^{\mathrm{b}}$ & $235.8^{\mathrm{a}}$ & $158.3^{\mathrm{b}}$ & $251.5^{\mathrm{c}}$ & 2.02 \\
\hline Water intake $(\mathrm{kg} / \mathrm{d})$ & $16.4^{\mathrm{a}}$ & $12.6^{\mathrm{b}}$ & $15.5^{\mathrm{a}}$ & $11.0^{\mathrm{b}}$ & 0.28 \\
\hline Body weight (kg) & 47.5 & 50.4 & 49.3 & 51.7 & 0.22 \\
\hline
\end{tabular}

SEM, standard error of the mean; DM, dry matter; TDN, total digestible nutrients; DCP, digestible crude protein.

${ }^{1}$ Ad libitum feeding of roughly crushed alfalfa hay cubes.

${ }^{a, b}$ Means with different superscripts within a row are significantly different $(\mathrm{p}<0.05)$.

Values are means of ten animals. 
Table 6. Effects of daytime or nighttime cooling on milk composition and component yield in goats exposed to a hot environment

\begin{tabular}{|c|c|c|c|c|c|}
\hline Item & $\begin{array}{c}\text { Hot } \\
\left(32^{\circ} \mathrm{C}\right)\end{array}$ & $\begin{array}{c}\text { Daytime } \\
12 \mathrm{~h} \text { cooling }\end{array}$ & $\begin{array}{c}\text { Hot } \\
\left(32^{\circ} \mathrm{C}\right)\end{array}$ & $\begin{array}{l}\text { Nighttime } \\
12 \mathrm{~h} \text { cooling }\end{array}$ & SEM \\
\hline Milk yield (g/d) & $2,098.2$ & $2,047.0$ & $2,083.3$ & $2,137.8$ & 18.622 \\
\hline \multicolumn{6}{|c|}{ Milk composition (\%) } \\
\hline Fat & $2.73^{\mathrm{b}}$ & $3.10^{\mathrm{a}}$ & $2.99^{\mathrm{a}}$ & $3.21^{\mathrm{a}}$ & 0.027 \\
\hline Protein & $2.52^{\mathrm{b}}$ & $2.86^{\mathrm{a}}$ & $2.66^{\mathrm{b}}$ & $2.93^{\mathrm{a}}$ & 0.019 \\
\hline Lactose & $3.83^{\mathrm{b}}$ & $4.07^{\mathrm{a}}$ & $3.85^{\mathrm{b}}$ & $4.09^{\mathrm{a}}$ & 0.015 \\
\hline Solids-not-fat & $7.41^{\mathrm{b}}$ & $7.99^{\mathrm{a}}$ & $7.57^{\mathrm{b}}$ & $8.08^{\mathrm{a}}$ & 0.029 \\
\hline Total solid & $10.15^{\mathrm{b}}$ & $11.10^{\mathrm{a}}$ & $10.57^{\mathrm{b}}$ & $11.29^{\mathrm{a}}$ & 0.048 \\
\hline \multicolumn{6}{|c|}{ Component yield (g/d) } \\
\hline Fat & $58.4^{\mathrm{b}}$ & $64.3^{\mathrm{a}}$ & $63.3^{\mathrm{a}}$ & $69.5^{\mathrm{c}}$ & 0.863 \\
\hline Protein & $52.8^{\mathrm{b}}$ & $58.1^{\mathrm{a}}$ & $55.5^{\mathrm{b}}$ & $62.1^{\mathrm{c}}$ & 0.581 \\
\hline Lactose & $80.8^{\mathrm{b}}$ & $83.3^{\mathrm{a}}$ & $80.4^{\mathrm{b}}$ & $87.6^{\mathrm{c}}$ & 0.849 \\
\hline Solids-not-fat & $155.9^{\mathrm{b}}$ & $163.1^{\mathrm{a}}$ & $158.0^{\mathrm{b}}$ & $172.3^{\mathrm{c}}$ & 1.552 \\
\hline Total solid & $214.3^{\mathrm{b}}$ & $227.5^{\mathrm{a}}$ & $221.3^{\mathrm{b}}$ & $241.9^{c}$ & 2.486 \\
\hline
\end{tabular}

SEM, standard error of the mean.

${ }^{\mathrm{a}, \mathrm{b}}$ Means with different superscripts within a row are significantly different $(\mathrm{p}<0.05)$.

Values are means of ten animals.

hot environment. Rectal temperature increased significantly ( $\mathrm{p}<0.05$ ) from $39.1^{\circ} \mathrm{C}$ in the thermoneutral environment to $40.2^{\circ} \mathrm{C}$ in the hot environment. These changes in physiological parameters in hot environment indicate that the animals are exposed to heat stress.

It is well known that when animals are exposed to stress, corticotropin-releasing factor (CRF) plays a major role in integrating the endocrine and autonomic response to this stress through the activation of both the pituitary-adrenal axis and the sympathetic nervous system (Antoni, 1986; Menzaghi et al., 1993). Sunagawa et al. (2000) reported that a continuous intraventricular infusion of CRF significantly decreased feed and water intake in sheep. It was reported that heat stress decreased dry matter intake and milk yield in lactating cows (West, 2003). However, limited information is available on the magnitude in depression of feed intake and milk production due to heat stress in lactating goats (Lu, 1989). Due to the heat stress, TDN and DCP intakes, and body weight in this experiment all significantly $(\mathrm{p}<0.05)$ decreased by $38 \%, 41 \%$, and $13 \%$ respectively (Table 2). Compared to the thermoneutral environment, milk yield, milk components percentage of fat, protein, lactose, solid-not-fat and total solid, and each components yields in the hot environment decreased by a significant $(\mathrm{p}<0.05) 14 \%, 14 \%, 13 \%, 8 \%, 8 \%, 10 \%, 26 \%$, $32 \%, 21 \%, 22 \%$, and $23 \%$, respectively (Tables 2, 3, and 4). While TDN and DCP intakes of lactating goats is significantly lower than lactating cows, from the results of these experiments, it is clear that heat stress plays a significant role in TDN and DCP intakes, and milk production performance.

Daytime cooling or nighttime cooling for reducing heat

\section{stress}

The unstocked ruminants in Japan are traditionally fed twice a day during the daytime. Heat production in dairy cows (heifers, lactating, and dry cows) increases with feeding. It has been reported that the amount of heat production is determined by the volume of feed intake (Puruwanto et al., 1990; Ando et al., 1997). It has also been reported that heat production and mean body temperature follows a diurnal pattern over the course of a day peaking 3 hours following afternoon feeding and then gradually declining to its lowest point prior to morning feeding.

In this experiment, daytime cooling treatment was conducted during the day when heat production is at its highest. The nighttime cooling treatment was conducted during the night when heat production is low and heat dissipation is at its highest (Figures 1 and 2). Scott et al. (1983) reported that nighttime cooling enhanced heat dissipation, reducing rectal temperatures when were elevated by high daytime temperatures in dairy cows. The result of the experiment, based on the heat stress indicators TDN and DCP intake, was that nighttime cooling was more effective $(\mathrm{p}<0.01)$ than daytime cooling (Table 2$)$. These results suggest that it is more effective to conduct cooling to relieve heat stress during the nighttime period when heat dissipation is highest than to cool during the peak heat production daytime hours.

\section{Daytime cooling or nighttime cooling for improving milk production in hot environment}

Factors involved in the decrease of milk yield and milk composition in a hot environment include indirect actions such as the decline in feed intake and direct actions including the suppression of milk production in the 
mammary glands. In this experiment, nighttime cooling was more effective than daytime cooling in reducing declines in TDN and DCP intakes in a hot environment (Table 5). When lactating cows were exposed to hot environment, plasma concentrations of growth hormone (Mitra et al., 1972), triiodothyronine and thyroxine (Magdub et al., 1982; Jonson et al., 1988) declined. These hormones are directly related to milk production in the mammary glands. It has been reported that in a thermoneutral environment, plasma growth hormone concentration in goats (Jin et al., 2013), steers (Kasuya et al., 2008) and monkeys (Quabbe et al., 1981) was higher during the night than the day. It was reported that the administration of growth hormone in lactating cows produced high levels of milk and milk components yields (Peel et al., 1987; Burton et al., 1994). It was also reported that the administration of growth hormone directly into the mammary artery in goats produced high milk yields (Prosser et al., 1989). However, it has been reported that evaporative cooling in heat stressed lactating cows did not increase plasma triiodotyronine $\left(\mathrm{T}_{3}\right)$, thyroxine $\left(\mathrm{T}_{4}\right)$ and growth hormone concentrations but milk component yields increased due to increases in circulating blood volume in association with an increase in feed intake (Chaiyabutr et al., 2008). From these reports, it is thought that the reason that nighttime cooling is more effective than daytime cooling in reducing declines in milk production in lactating goats in a hot environment is because feed intake increases with nighttime cooling and it increases the supply of nutrients to the mammary glands for milk synthesis.

The results of this experiment indicate that nighttime cooling is more effective than daytime cooling in the reduction of milk production declines in lactating goats in a hot environment. From the results of these experiments, it is thought that other types of cooling may well prove suitable for lactating cows raised in an open barn environment.

\section{ACKNOWLEDGMENTS}

We thank Mr. Glenn Mcllvride for his English proofreading on this manuscript. This research was funded in part by a grant from the Uruma Foundation. The computation was mainly carried out using the computer facilities in the Research Institute for Information Technology, Kyushu University.

\section{REFERENCES}

Ando, S., M. C. Mundia, Y. Nakamura, and S. Yamamoto. 1997. Effect of feed intake levels on heart rate, heat production, and mean body temperature of Holstein heifers. Anim. Sci. Technol. 68: $177-184$.

Antoni, F. A. 1986. Hypothalamic control of adrenocorticotropin secretion: Advances since the discovery of 41-residue corticotropin-releasing factor. Endocrine Rev. 7:351-378.
AOAC. 1990. Official Methods of Analysis. 15th. Ed. Association of Official Analytical Chemists. Arlington, VA, USA.

Burton, J. L., B. W. McBride, E. Block, D. R. Glimm, and J. J. Kennely. 1994. A review of bovine growth hormone. Can. J. Anim. Sci. 74:167-201.

Hales, J. R. S. 1974. Physiological responses to heat. In Environmental Physiology (Eds. A. C. Guyton, D. Horrobin, and D. Robertshaw). Butterworths, University Park Press, London, UK. pp. 107-162.

Chaiyabutr, N., S. Chanpongsang, and S. Suadsong. 2008. Effects of evaporative cooling on the regulation of body water and milk production in crossbred Holstein cattle in a tropical environment. Int. J. Biometerolol. 52:575-585.

Jin, J., T. Yaegashi, and T. Hashizume. 2013. Effects of photoperiod on the secretion of growth hormone and prolactin during nighttime in female goats. Anim. Sci. J. 84:130-135.

Johnson, H. D. 1987. Bioclimate effects on growth, reproduction and milk production. In: Bioclimatology and the adaptation of livestock (Ed. H. D. Johnson). Elsevier, Amsterdam, Netherlands. pp. 35-57.

Kadzere, C. T., M. R. Murphy, N. Silanikove, and E. Maltz. 2002. Heat stress in lactating cows: A review. Livest. Prod. Sci. 77: 59-91.

Kasuya, E., S. Kushibiki, K. Yayou, K. Hodate, and M. Suutoh. 2008. Light exposure during night suppresses nocturnal increase in growth hormone secretion in Holstein steers. J. Anim. Sci. 86: 1799-1807.

Lu, C. D. 1989. Effects of heat stress on goat production. Small Rumin. Res. 2:151-162.

Magdub, A., H. D. Johnson, and R. L. Belyea. 1982. Effect of environmental heat and dietary fiber on thyroid physiology of lactating cows. J. Dairy Sci. 65:2323-2331.

Menzaghi, F., S. C. Heinrichs, E. M. Pich, F. Weiss, and G. F. Koob. 1993. The role of limbic and hypothalamic corticotropin-releasing factor in behavioral responses to stress. Ann. NY Acad. Sci. 697:142-154.

Mitra, R., G. I. Christison, and H. D. Johnson. 1972. Effect of prolonged thermal exposure on growth hormone $(\mathrm{GH})$ secretion in cattle. J. Anim. Sci. 34:776-779.

Nagamine I. and K. Sunagawa. 2014. Effect of original formula feed feeding levels and environmental temperature on milk production in goats. J. Warm Region. Scoc. Anim. Sci. 57: 131-140.

Peel, C. J. and D. E. Bauman. 1987. Somatotropin and lactation. J. Dairy Sci. 70:474-486.

Prosser, C. G., I. R. Fleet, and R. B. Heap. 1989. Action of IGF-I on mammary function. In: Biotechnology in Growth Regulation (Eds. R. B. Heap, C. G. Prosser, and G. E. Lamming). Butterworth, University Park, London, UK. pp. 141-151.

Purwanto, B. P., Y. Abo, R. Sakamoto, F. Furumoto, and S. Yamamoto. 1990. Diurnal patterns of heat production and heart rate under thermoneutral conditions in Holstein Friesian cows differing in milk production. J. Agric. Sci. 114:139-142.

Quabbe, H-J., M. Gregor, C. Bumke-Vogt, A. Eckhof, and I. Witt. 1981. Twenty-four-hour pattern of growth hormone secretion in the Rhesus monkey: Studies including alterations of the sleep/wake and sleep stage cycles. Endocrinology 109:513-522. SAS. 1990. SAS/STAT User's Guide: Volume 2, Version 6.4th Ed. 
SAS Institute Inc., SAS Campus Drive, Cary, NC, USA 27523.

Scott, I. M., H. D. Johnson, and G. L. Hahn. 1983. Effect of programmed diurnal temperature cycles on plasma thyroxine level, body temperature, and feed intake of Holstein dairy cows. Int. J. Biometeorol. 27:47-62.

Sunagawa, K., Y. Arikawa, M. Higashi, H. Matsuda, H. Takahashi, Z. Kuriwaki, Z. Kojiya, S. Uechi, and F. Hongo. 2002. Direct effect of a hot environment on ruminal motility in sheep. Asian Australas. J. Anim. Sci. 15:859-865.

Thang, T. V., K. Sunagawa, I. Nagamine, and G. Ogura. 2011. Plasma osmolality controls dry forage intake in large-type goats. Asian Australas. J. Anim. Sci. 24:1069-1085.
Yamamoto, S., J. A. McLean, and A. J. Downie. 1979. Estimation of heat production from heart-rate measurements in cattle. Br. J. Nutr. 42:507-513.

Van Soest, P. J., J. B. Robertson, and B. A. Lewis. 1991. Methods for dietary fiber, neutral detergent fiber, and nonstarch polysaccharides in relation to animal nutrition. J. Dairy Sci. 74: 3583-3597.

West, J. W. 1999. Nutritional strategies for managing the heatstressed dairy cow. J. Anim. Sci. 77:21-35.

West, J. W. 2003. Effects of heat-stress on production in dairy cattle. J. Dairy Sci. 86:2131-2144. 